\title{
The European Union (EU) after the Treaty of Lisbon
}

The Reform Treaty of Lisbon amending the Treaty on European Union (TEU) and the Treaty establishing the European Community (TEC) was signed at Lisbon on December 13, 2007.

The TEU radically altered the structure of what used to be the TEC, now called Treaty on the Functioning of the European Union (TFEU). It does away with the former pillar structure, thus abolishing the institutional structure of separate policy areas with regard to police and judicial co-operation in criminal matters.

Until the Lisbon Treaty came into force in December 2009, the EU Data Protection Directive (95/46/EC) exempted second and third pillar issues from data protection scrutiny. The Lisbon Treaty now makes such scrutiny possible. With the planned revision of the Data Protection Directive in November 2011, data controllers processing sensitive data, including surveillance systems, may be obliged to subject them to privacy impact assessment.

\section{Competences, Legal Acts and Institutions}

There are three basic types of Union Competence:

- exclusive competences of the Union, Art. 2(1) TFEU, according to which the member states may no longer act unless they are empowered to implement Union acts (few areas, listed in Art. 3 TFEU).

- shared competences between the Union and the member States - Art. 2(2) TFEU (principal areas are listed in Art. 4 TFEU).

supporting competences, coordinating or supplementing competences of the Union - Art. 2(5) TFEU (areas are listed in Art. 6 TFEU).

To exercise the Union's competences, the institutions use legal acts as described in Art. 288 TFEU:
- regulations: they are directly applicable in all member states and automatically become part of the national legal order.

- directives: they must be implemented into national law within a certain period.

- decisions: they have to be concrete and specific to a limited number of persons in the EU.

- recommendations and opinions: they have no binding force.

The institutional framework of the EU (Art. 13-19 TEU) includes

- the European Parliament which represents voters in the EU's member states

the European Council (EC) which is still the leading political institution and directs EU policy-making

the Commission which represents the EU's member governments

- the Court of Justice (EJC)

- the European Central Bank (ECB)

- bodies, offices and agencies, e.g.: the Economic and Social Committee, the Committee of Regions and the High Representatives of the Union for Foreign Affairs and Security which takes part in the work of the EC.

\section{Role of the Institutions}

While the power to initiate laws is held by the Commission, Parliament and Council are the principal actors in the law-making process. Their roles vary depending on the particular legislative procedure.

- The ordinary legislative procedure, formerly known as "codecision procedure", applies to the majority of legislation. It is based on the principle of parity, neither Parliament nor Council can adopt legislation alone without the agreement of the other.

- Consultation procedure is a special legislative procedure under Article 289(2) TFEU, whereby the Council can adopt legislation after asking the Parliament for its opinion. The Council is not bound by the Parliament's opinion.

- Consent procedure also is a special legislative procedure under Article 289(2) TFEU. which gives Parliament the right of veto; it has the legal power either to accept or to reject any legislative proposal.

The Treaty of Lisbon has also extended the circumstances in which the Parliament's consent is required for the conclusion of an international agreement. Hence, inter alia, also for the most recent EU-US Passenger Name Record Agreement, the European Parliament's consent is required in order to conclude the agreement.

\section{Fundamental Rights and Principles}

Under Art. 2 TEU the Union refers to the values of respect for human dignity, freedom, democracy, equality, the rule of law and the respect for human rights including the rights of persons belonging to minorities.

According to Art. 6(1) TEU the Charter of Fundamental Rights (ECFR) shall have the same legal value as the Treaties. According to Art. 6(3) TEU, the fundamental rights guaranteed by the European Convention on Human Rights (ECHR) and fourteen additional protocols constitute general principles of the Union's law.

Once the Union will have acceded to the ECHR (see Art. 6(2) TEU), the Union's legal acts will also be subject to the jurisdiction of the European Court of Human Rights (ECHR). ${ }^{1}$ Hence, legal acts interfering with the individual's right to privacy will also be judged under Art. 8 ECHR (Right to respect for private and family life). ${ }^{2}$

\footnotetext{
$1 \mathrm{Cf}$ the article of Streinz in this issue.

2 See the contribution of Petri in this issue on the example of the Retention Directive, s. Tinnefeld
} on the example of privacy and environment law. 